\title{
PENGGUNAAN METODE BLENDED LEARNING PADA PEMBELAJARAN SKILL LAB KEPERAWATAN DALAM MENINGKATKAN KOGNITIF DAN PSIKOMOTOR
}

\author{
Kholifah Hasnah ${ }^{1)}$, Siti Nur Solikah ${ }^{2)}$ \\ ${ }^{1,2}$ Politeknik Insan Husada Surakarta \\ e-mail rasyidifah09@gmail.com
}

\begin{abstract}
ABSTRAK
Pemerintah saat ini telah menetapkan peraturan social distancing seiring dengan adanya pandemi Covid-19. Peraturan tersebut termasuk untuk seluruh Perguruan Tinggi agar menerapkan pembelajaran jarak jauh. Hal ini menjadi tantangan bagi Perguruan tinggi Kesehatan dengan pembelajaran yang mengharuskan adanya interaksi langsung antara dosen dan mahasiswa. Sehingga diperlukan metode pembelajaran yang sesuai dengan tetap menerapkan peraturan social distancing, salah satunya yaitu metode blended learning. Tujuan dari penelitian ini adalah mengetahui penggunaan metode blanded learning pada pembelajaran skill lab keperawatan, dalam meningkatkan kognitif dan psikomotor mahasiswa. Tekhnik pengambilan sampel menggunakan purpsive sampling dengan jumlah sampel adalah 50 mahasiswa. Metode yang digunakan adalah pre eksperimen dengan pendekatan one grouppretest-posttest witout control. Hasil uji analisa data pada kognitif dan psikomotor menunjukan nilai $p$ value $0.000(<0.05)$ yang bermakna ada peningkatan kognitif dan psikomotor mahasiswa dengan penggunaan metode blanded learning. Kesimpulan, terdapat peningkatan kognitif dan psikomotor mahasiswa dengan penggunaan metode blanded learning pada pembelajaran skill lab keperawatan. Saran perlu adanya penelitian selanjutnya yang berkaitan dengan penerapan metode blended learning terhadap aspek yang lebih luas dalam pembelajaran seperti tujuan pembelajaran atau motivasi belajar mahasiswa.
\end{abstract}

Kata kunci: blended learning; kognitif; psikomotor

\begin{abstract}
Government has set social distancing regulations in line with the COVID-19 pandemic. These regulations include all universities to implement distance learning. This is a challenge for Health Colleges with learning that requires direct interaction between lecturers and students. So we need an appropriate learning method while still applying social distancing rules, one of which is the blended learning method. The purpose of this study was to determine the use of blended learning methods in nursing lab skills learning, in improving students' cognitive and psychomotor skills. The sampling technique used purpsive sampling with a sample size of 50 students. The method used in this study was pre-experimental with a one-group pretest-posttest approach with control. The results of the data analysis test on cognitive and psychomotor showed a p value of $0.000(<0.05)$ which means there was an increase in cognitive and psychomotor students. In conclusion, there is an increase in students' cognitive and psychomotor by using blended learning methods in nursing lab skills learning. Suggestions need for further research related to the application of the blended learning method to broader aspects of learning such as learning objectives or student learning motivation.
\end{abstract}

Keywords: blended learning; cognitive; psychomotor 


\section{PENDAHULUAN}

Sistem pendidikan di Indonesia saat ini mengalami perubahan akibat pandemi Covid-19. Pemerintah melalui Kementrian Pendidikan dan Kebudayaan menerapkan kebijakan belajar dari rumah sejak Maret 2020. Hampir seluruh Perguruan Tinggi di Indonesia merespon kebijakan tersebut dengan menerapkan pembelajaran jarak jauh. Salah satu pembelajaran yang diterapkan adalah dengan pembelajaran secara online (Hikmat, 2020)

Pembelajaran secara online dapat terlaksana apabila didukung dengan perangkat yang sesuai untuk mengakses informasi yang dibutuhkan(Gikas J \& Grant M M, 2016). Penggunaan perangkat tekhnologi pada pembelajaran online mampu merombak cara penyampaian pengetahuan dan dapat menjadi alternatif pembelajaran yang dilaksanakan dalam kelas perkuliahan (Zhang D Zhao J L Zhou L \& Nunamaker J F, 2014).

Permasalahan yang juga menjadi tantangan bagi perguruan tinggi dengan sistem pembelajaran online lebih dirasakan bagi perguruan tinggi kesehatan, salah satunya perguruan tinggi keperawatan. Hal tersebut dikarenakan Perguruan Tinggi Keperawatan memiliki perkuliahan yang mengharuskan interaksi dosen dan mahasiswa serta adanya role model yang diberikan dosen kepada mahasiswa, yaitu skill lab keperawatan. 
Pembelajaran membutuhkan metode yang tepat agar pembelajaran skill lab yang diajarkan secara online dapat tercapai tujuan pembelajarannya. Metode yang digunakan harus tetap menekankan pada setting interaksi dan ketrampilan klinis yang sesuai dengan pembelajaran skill lab keperawatan. Metode tersebut salah satunya adalah blended learning. Dengan metode ini akan terjadi interaksi secara virtual sehingga dosen dapat mendomenstrasikan jenis skill lab keperawatan yang diberikan kemahasiswa. Pembelajaran ini lebih berpusat pada mahasiswa karena mampu memunculkan tanggung jawab mandiri, sehingga menuntut mahasiswa mempersiapkan sendiri pembelajaranya (Sun, 2018).

Berdasarkan uraian diatas penulis ingin mengetahui metode blended learning pada pembelajaran skill lab keperawatan dalam meningkatkan kognitif dan psikomotormahasiswa.

Tujuan khusus penelitian ini untuk mengetahui metode blended learning dalam meningkatkan kognitifdan psikomotor mahasiswa pada pembelajaran skill lab keperawatan.

\section{METODE PENELITIAN}

Penelitian ini menggunakan rancangan pra eksperimen dengan pendekatan pretest posttest group without control. Populasi dari penelitian ini adalah mahasiswa keperawatan Akademi Keperawatan (Akper) Insan Husada semester tiga dengan jumlah 97 mahasiswa. Alasan memilih mahasiswa akper Insan Husada karena memiliki mata kuliah skill lab keperawatan dengan menerapkan salah satu model pembelajaran online sesuai kebijakan pemerintah Surakarata. Selain itu mahasiswa Akper Insan Husada Surakarta belum pernah dilaksanakan metode pembelajaran blended learning sehingga diharapkan menjadi uji coba untuk dijadikan acuan metode pembelajaran dalam kurikulum pembelajaran akper insan husada surakarta.

Pengambilan sampel pada penelitian ini menggunakan purposive sampling yaitu mahasiswa akper insan husada semester 3 yang mendapat mata kuliah skill lab keperawatan KMB II.

Jumlah sampel dalam penelitian ini adalah 50 mahasiswa. Kriteria inklusi sampel adalah mahasiswa yang mendapatkan matakuliah skill lab keperawatan yaitu skill lab keperawatan KMB 2, mahasiswa yang dapat mengikuti proses pembelajaran dengan metode blended learning serta mahasiswa yang pada saat tes screaning swab antibodi dinyatakan non reaktif dan dapat mengikuti sesi pembelajaran offline. Alat ukur berupa kuesioner untuk mengukur kognitif mahasiswa dan diberikan checklist penilaian observasi untuk mengukur psikomotor mahasiswa.

Data yang akan diukur sebagai indikator kognitif mahasiswa meliputi pengetahuan dasar, tujuan, manfaat, indikasi dari 8 komponen skill yang diajarkan pada mata kuliah skill lab KMB 2 yaitu perawatan luka post operasi, Range of Motion (ROM), pemasangan kateter, pemeriksaan saraf kranial, perawatan luka bakar, pemeriksaan GCS, bladder training, dan pemeriksaan gula darah. Seluruh komponan skill tersebut akan diajarkan dengan metode blended learning.

Dosen akan memberikan materi skill lab online melalui demosntrasi secara virtual dengan video pembelajaran dan google meet. Sedangkan pembelajaran offline diberikan langsung dengan tatap muka di lab keperawatan. Data yang akan diukur sebagai indikator kognitif dan psikomotor terkait dengan delapan komponen skill keperawatan KMB 2. Pre test pada indikator kognitif akan 
dinilai dengan kuesioner sebelum pembelajaran dilaksanakan yaitu tentang pengetahuan umum, pengetahuan dasar, tujuan, manfaat, indikasi dari setiap masing - masing skill keperawatan. Sebagai post testmahasiswa akan diukur kembali dengan kuisioner yang sama setelah seluruh pembelajaran dilaksanakan.

Pre test untuk indikator psikomotor mahasiswa dilakukan dengan mahasiswa membuat video terkait skill yang akan diajarkan sebelum pelaksanaan pembelajaran online untuk kemudian diukur dengan checklist penilaian sesuai dengan prosedur tindakan. Sebagai post-test mahasiswa akan diuji secara langsung oleh dosen dengan menggunakan lembar checklist penilaian yang dilakukan di laboratorium mini hospital keperawatan.

Materi pembelajaran untuk delapanskill keperawatan diberikan dengan metode blended learning yaitu sebagaian materi disampaikan secara online dan sebagaian secara offline. Satu skill keperawatan diberikan dalam dua kali pertemuan yaitu pertemuan pertama untuk membahas teori dan konsep yang terkait dengan skill keperawatan dan pada pertemuan kedua penyampaian demonstrasi skill keperawatan. Materi diberikan dengan durasi 100 menit tiap pertemuan dengan skill keperawatan yang berbeda. Pembelajaran online dilakukan melalui video yaitu dosen mendemostrasikan skill tindakan keperawatan dan disampaikan melalui link untuk kemudian didiskusikan dengan google meet. Untuk pembelajaran offline disampaikan langsung pada pertemuan di laboratorium keperawatan.

Evaluasi akhir berupa post-test untuk indikator kognitif dan psikomotor. Post-test untuk indikator kognitif dilaksanakan secara online menggunakan kuesioner yang dikirim melalui google form. Sedangkan post test untuk indikator psikomotor dilaksanakan offline atau tatap muka di laboratorium keperawatan. Responden melakukan tindakan skill keperawatan yang diukur menggunakan checklist lembar observasi. Seluruh data dari kognitif maupun psikomotor dilakukan uji normalitas serta uji analisa data untuk mengetahui pengaruhnya menggunakan uji paired t-test

\section{HASIL DAN PEMBAHASAN}

Hasil penelitian yang telah dilaksnakan adalah sebagai berikut :

Tabel 1. Distribusi karakteristik responden di politeknik Insan

Husada ( $\mathrm{n}=50)$

\begin{tabular}{cccc}
\hline & Karakteristik & f & \% \\
\hline $\begin{array}{c}\text { Jenis } \\
\text { Kelamin }\end{array}$ & & & \\
& Laki-laki & 8 & $16 \%$ \\
& Perempuan & 42 & $84 \%$ \\
Umur & & & \\
& 19 & 7 & $14 \%$ \\
& 20 & 32 & $64 \%$ \\
& 21 & 7 & $14 \%$ \\
& 22 & 3 & $6 \%$ \\
& 23 & 1 & $2 \%$
\end{tabular}

(Sumber Data Primer, 2021)

Tabel 1 menunjukan bahwa responden berdasarkan jenis kelamin paling banyak adalah perempuan sebesar $84 \%$ dan laki laki $16 \%$. Berdasarkan umur paling banyak responden dengan umur 20 tahun berjumlah $64 \%$, dan paling sedikit adalah responden dengan umur 23 tahun yang berjumlah $2 \%$.

Berdasarkan Tabel 1 didapatkan hasil bahwa responden paling banyak adalah perempuan dengan jumlah 84\%. Perbedaan jenis kelamin membentuk persepsi yang berbeda. Menurut penelitian yang dilakukan oleh Erdian (2019) bahwa perempuan maupun laki- laki memiliki tingkat kognitif yang berbeda, namun hal ini 
tidak memberikan fakta yang kuat bahwa perempuan memiliki tingkat kognitif yang lebih bak. Hasil penelitian juga menunjukan bahwa responden paling banyak usia 20 tahun $(64 \%)$ dimana masuk dalam tingkat umur yang produktif. Semakin cukup umur maka seseorang akan memiliki tingkat kematangan secara kognitif.

Tabel 2. Distribusi responden berdasarkan kognitif dan psikomotor $(\mathrm{n}=50)$

\begin{tabular}{lccc}
\hline & Mean & SD & p value \\
\hline Kognitif & & & 0.000 \\
Pre test & 49.20 & 13.029 & \\
Post test & 58.10 & 14.945 & \\
Psikomotor & & & 0.000 \\
Pre test & 63.86 & 9.010 & \\
Post tes & 89.84 & 5.331 & \\
\hline
\end{tabular}

(Sumber Data Primer, 2021)

$\begin{array}{llr}\text { Berdasarkan } & \text { Tabel } 2 & \text { dapat } \\ \text { diketahui bahwa } & \text { metode }\end{array}$
pembelajaran blended learning pada skill keperawatan secara kognitif responden memiliki nilai rata rata (mean) pada pre test adalah 49.20 dan post test 58.10 dengan nilai signifikansi (0.000) yang artinya ada pengaruh metode blended learning dalam meningkatkan kognitif pada pembelajaran skill keperawatan. Nilai rata - rata secara psikomotor pada pre test adalah 63.86 dan post test 89.84 dengan nilai signifikansi $(\mathrm{p}$ value $=0.000$ ) yang berarti terdapat pengaruh yang signifikan pada metode blended learning dalam meningkatkan psikomotor pada pembelajaran skill keperawatan.

a. Peningkatan kognitif mahasiswa dengan metode blended learning.

Berdasarkan hasil penelitian didapatkan nilai rata-rata pre test pada indikator kognitif adalah 49.20 dan nilai nilai rata - rata post test adalah
58.10, hal ini menunjukan ada rentang peningkatan nilai pada kognitif mahasiswa dengan metode pembelajaran blended learning. Meningkatnya kemampuan kognitif menggunakan metode pembelajaran blended learning diartikan sebagai pemahaman yang mendasar sehingga mahasiswa mampu memahami suatu situasi. Kemampuan kognitif sangat penting bagi mahasiswa yang belajar untuk memahami setiap tujuan pembelajaran yang memiliki arti mendasar pada proses pembelajaran(Jati H, 2018). Menurut Erdian (2019) indikator kognitif mengacu kepada kemampuan mahasiswa dalam memahami suatu materi. Penggunaan metode blended learning dapat menciptkan suasan belajar yang nyaman dalam diskusi antara dosen dan mahasiswa selama pembelajaran. Mahasiswa tidak merasa tekanan secara psikologis seperti ketika belajar secara langsung. Hal ini membuat mahasiswa merasa rileks dalam proses pembelajaran sehingga memudahkan mahasiswa dalam proses menerima materi yang disampaikan dosen(Sun, 2018). Pembelajaran dengan metode blended learning khusunya untuk online mampu menstimulasi mahasiswa untuk berekspresi dalam bertanya dan diskusi selama proses pembelajaran(Sadikin Ali, 2020). Proses pembelajaran yang menyenagkan ini membuat mahasiswa mudah menerima materi yang disampaikan sehingga dapat meningkatkan kognitif mahasiswa dalam belajar.

Pembelajaran dengan metode blended learning mampu menumbuhkan kemandirian belajar (self regulated learning) dalam meningkatkan kognitif mahasiswa(Oknisih N \& Suyoto S, 2019). Menurut Kuo et al (2018) mengatakan bahwa metode blended learning dengan pembelajaran online lebih berpusat pada mahasiswa yang 
dapat memunculkan tanggung jawab dan otonomi belajar (learning otonomy).

Mahasiswa dituntut untuk mempersiapkan sendiri pembelajaran nya, mengevaluasi, mengatur dan secara simultan dapat mempertahankan motivasi dalam belajar(Sun, 2018). Hal ini sejalan dengan penelitian yang dilakukan oleh Gunawan (2018) bahwa hasil belajar mahasiswa dalam kemampuan kognitif mampu meningkat melalui penerapan metode blended learning. Kegiatan diskusi pada proses pembelajaran dengan metode blended learning menunjukan bahwa mahasiswa lebih aktif dalam mencari sumber sumber belajar.

Proses pendidikan khususnya dalam pembelajaran diperlukan adanya metode pembelajaran yang sesuai karena berpengaruh terhadap hasil belajar dan capaian kognitif mahasiswa. Sehingga pemilihan metode yang tepat sangat menetukan hasil belajar tersebut. Pada penelitian ini ditemukan bahwa metode blended learning dapat meningkatkan kognitif mahasiswa pada skill keperawatan. Menurut Heinze (2018) pembelajaran dengan blended learning merupakan metode yang dapat meningkatkan hasil belajar mahasiswa pada kognitif, afektif dan juga psikomotor. Implementasi pembelajaran blended learning mampu menstimulai fokus mahasiswa sehingga meningkatkan hasil belajar pada mata kuliah simulasi seperti pada skill keperawatan(Syarif I, 2017). Hal ini sesuai dengan penelitian yang dilakukan oleh Rizkiyah (2015) bahwa pelaksanaan pembelajaran dengan blended learning dapat meningkatkan hasil belajar pada aspek kognitif, afektif dan psikomotor.

Penelitian ini dilakukan sebagai respon kebijakan pemerintah dalam system pembelajaran di era pandemic Covid-19. Pemerintah melalui Kementrian Pendidikan dan
Kebudayaan menerapkan kebijakan belajardari rumah untuk menerapkan social distancing. Hal tersebut mengharuskan sistem pendidikan untuk menggunakan metode pembelajaran yang sesuai dengan tetap memperhatikan capaian hasil belajar mahasiswa. Penggunaan metode blended learning memungkinkan mahasiswa dan dosen untuk melaksanakan proses pembelajaran dengan tetap menjaga social distancing. Tindakan ini sesuai dengan rekomendasi WHO pada tahun 2020 untuk mengurangi adanya kerumunan diarea kampus agar dapat mencegah penularan Covid-19.

\section{b. Peningkatan Psikomotor mahasiswa dengan metodepembelajaran blended learning}

Pada penelitian ini pembelajaran dengan metode blended learning menggunakan vidio demonstrasi praktek skill keperawatan sebagai simulasi untuk aspek psikomotor. Hasil dari penelitian ini didapatkan adanya peningkatan psikomotor mahasiswa pada pembelajaran dengan metode blended learning. Hal ini sesuai dengan penelitian yang ditemukan oleh Garison (2016) bahwa demonstrasi dari video merupakan bentuk virtual yang menuntut mahasiswa untuk sistematis dalam melakukan percobaan sehingga mampu meningkatkan psikomotor dalam melakukan percobaan hands on.

Hal ini mampu mengonfirmasi praktek secara hands on mahasiswa dengan teori melalui vidio pembelajaran sehingga pembelajaran menjadi lebih efisien, efektif dan fleksibel. Metode blended learning juga merupakan integrasi yang efektif antara pembelajaran offline dengan online. Mata kuliah skill lab keperawatan memiliki unsur pembelajaran berupa tindakan yang 
tidak hanya dapat disampaikan dengan teori saja, sehingga menuntut dosen agar menggunakan metode pembelajaran dengan tetap memperhatikan capaian hasil belajar dariaspek psikomotor. Blended learning merupakan metode pembelajaran yang menggabungkan antara tatap muka dengan pembelajaran online dengan menggunakan multimedia salah satunya adalah video agar materi yang bertujuan pada aspek psikomotor dapat tersampaikan (Abdullah, 2018).

Aspek psikomotor pada pembelajaran skill keperawatan berkaitan dengan ketrampilan dan kemampuan mahasiswa dalam menerima pengalaman belajar yang menjadi kelanjutan dari hasil belajar pada aspek kognitif(Sudijono Anas, 2016). Penelitian ini menggunakan vidio dalam integrasi metode blended learning dan menghasilkan adanya peningkatan pada aspek psikomotor mahasiswa. Menurut Padhila (2019) bahwa simulasi virtual klinis pada video demonstrasi skill keperawatan memunculkan retensi kognitif dan penalaran klinis yang merupakan dasar dari kelanjutan peningkatan psikomotor mahasiswa.

Hal yang mempengaruhi peningkatan psikomotor mahasiswa salah satunya adalah metode pembelajaran yang tepat digunakan dalam proses mempelajari suatu materi yang berkaitan dengan aspek psikomotor (Notoatmodjo, 2014). Seperti pada penelitian ini yang menggunakan metode blended learning dan mengakomodasikan video sebagai metode pembelajaran skill keperawatan.

Metode ini mampu memberikan rangsangan audio visual pada mahasiswa sehingga mampu memunculkan daya imajinasi tentang suatu materi yang disampaikan. Hal ini membuat mahasiswa memiliki pengalaman belajar yang kuatterhadap situasi dari demonstrasi pembelajaran yang dilihat sehingga mampu meningkatkan aspek kognitif yang menjadi dasar pengalaman psikomotor mahasiswa.

\section{KESIMPULAN}

a. Responden pada penelitian ini berjenis kelamin perempuan yang berjumlah 42 responden $(84 \%)$ dan yang berjenis kelamin laki-laki berjumlah delapan responden (16\%). Berdasarkan usia responden paling banyak adalah usia 20 tahun dengan jumlah 32 responden (64\%).

b. Hasil analisa uji t-test pada kognitif menunjukan nilai sig (2 tailed) sebesar $0,000(<0,05)$ yang berati ada peningkatan kognitif mahasiswa dengan metode blended learning pada pembelajaran skill lab keperawatan.

c. Hasil analisa uji t-test pada psikomotor menunjukan nilai sig (2 tailed) sebesar 0,000 $(<0,05)$ yang berarti ada peningkatan psikomotor mahasiswa dengan metode blended learning pada pembelajaran skill lab keperawatan.

\section{SARAN}

a. Mahasiswa

Mahasiswa perlu mengikuti perkembangan metode pembelajaran terlebih di era tekhnologi yang terus berkembang agar tercapaianya tujuan pembelajaran.

b. Peneliti

Perlu adanya penelitian selanjutnya yang berkaitan dengan penerapan metode blended learning terhadap aspek yang lebih luas dalam pembelajaran seperti tujuan pembelajaran atau motivasi belajar mahasiswa yaitu hubungan penerapan blended learning terhadap moivasi belajar mahasiswa.

c. Institusi

Melaksanakan evaluasi kurikulum yang berkaitan dengan penerapan metode blended learning agar dapat digunakan dalam model pembelajaran yang lebih inovatif. 


\section{UCAPAN TERIMA KASIH}

Terima kasih kami ucapkan kepada:

a. Kemendikbud-Ristek atas pendanaan hibah penelitian tahun anggaran 2021.

b. Direktur Politeknik Insan Husada Surakarta yang telah memberikan ijin pelaksanaan penelitian.

c. LPPM Politeknik Insan Husada Surakarta yang telah banyak membantu selama proses penelitian.

d. Seluruh rekan rekan dosen Politeknik Insan Husada Surakarta.

e. Mahasiswa Program Studi D3 Keperawatan Politeknik Insan Husada Surakarta sebagai responden dalam penelitian.

\section{REFERENSI}

1. Abdullah (2018). 'Model Blended Learning dalam Meningkatkan Pembelajaran': Jurnal Pendidikan dan Manajemen' Volume 7, Nomor 1, Juli 2018; p-ISSN 2442- 2401; eISSN 2477-5622.

2. Erdian. Ilmu Perilaku Kognitif, cetakan pertama. Jakarta: CV Sagung Seto; 2019. 1-122

3. Garrison, D Randy dan Heather Kanuka. 2016. Blended Learning: Unconvering its transformative Potential in Higher Education. Journal Internet and Higher Education. Vol. 7, 95-105, [Online], (https://scholar.google. co.id, diakses 10 Oktober 2016).

4. Gikas, J., \& Grant, M. M. (2016). Mobile computing devices in higher education: Student perspectives on learning with cellphones, smartphones \& social media. Internet and Higher Education. https://doi.org/10.1016/j.iheduc.201 $\underline{6.06 .002}$

5. Gunawan, Devirga N.S.

'Penerapan Model Pembelajaran

Blended Learning un-tuk Meningkatkan Aktivitas dan Hasil Belajar Siswa' Universitas NegeriMalang, Malang
6. Hikmat, et al (2020). Efektivitas Pembelajaran Daring Selama Masa Pandemi Covid-19. Karya Tulis Ilmiah. UIN Bandung. Doi : /30625/1/FISIP 20

7. Jati H. (2018), 'Efektivitas Model Blended Learning'. Jurnal Pendidikan Vokasi - 79 Vol 5, Nomor 1, Februari 2018, doi : 6074-15881-1-S 20(3)

8. Kuntarto, et al. (2016). Pengembangan Model Pembelajaran Blended Learning pada Aspek Learning Design. https://repository.unja.ac.id/626/

9. Kuo, Y. C., Walker, A. E., Schroder, K. E. E., \& Belland, B. R. (2018).

10. Interaction, Internet self-efficacy, and self-regulated learning as predictors of student satisfaction in online education courses. Internet and Higher Education. https://doi.org/10.1016/jiheduc.20 17.10 .001

11. Notoatmodjo.(2014). Metodologi Penelitian Kesehatan.Jakarta : PT. Rineka Cipta

12. Oknisih, N., \& Suyoto, S. (2019), 'Penggunaan aplikasi sebagai upaya kemandirian belajar siswa' Seminar nasional pendidikan dasar (Vol. 1, No. 01)

13. Padilha, José Miguel; Machado, Paulo Puga; Ribeiro, Ana; Ramos, José; Costa, Patrício. (2019). Clinical Virtual Simulation in Nursing Education: Randomized Controlled Trial. J Med Internet Res2019;21(3):e11529.[doi:10.2196 /11529]

14. Rizkiyah, A. (2015). Penerapan Blended Learning untuk Meningkatkan Hasil Belajar Siswa Pada Mata Pelajaran Ilmu Bangunan di Kelas x TGB SMK Negeri 7 Surabaya. Jurnal Kajian Pendidikan Teknik Bangunan

15. Sadikin Ali. (2020). Pembelajaran daring ditengah covid 19 : Jurnal Ilmiah Pendidikan, Vol. 06, No. 02 
(2020), Hal. 214 - 224, doi : 24717 3-1020200706\%20

16. Sudijono, Anas. (2016). Pengantar Evaluasi Pendidikan. Jakarta: PT Raja Grafindo Persada.

17. Syarif, I. (2017), 'Pengaruh Model Blended Learning terhadap Motivasi dan

18. Prestasi Belajar Siswa '. Jurnal Pendidikan Vokasi, 2(2).234-249.
19. Sun, S. Y. H. (2018). Learner perspectives on fully online language learning. Distance Education. https://doi.org/10.1080/01587919.2 $\underline{017.891428}$

20. Zhang, D., Zhao, J. L., Zhou, L., \& Nunamaker, J. F. (2014). Can elearning replace classroom 